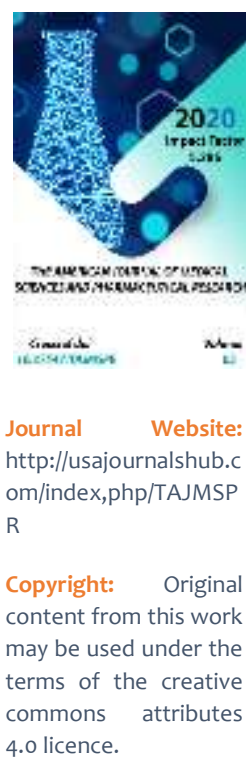

\title{
Role Play Technology In Pharmacology Classes
}

\author{
Sh. T. Makhmaraimov \\ Lecturer, Tashkent State Medical Academy Termez Branch, Termiz, Uzbekistan
}

\section{ABSTRACT}

The article describes the methodology of using the technology of role-playing games in practical classes at the university, which belongs to the advanced pedagogical methods. For, a problem situation, solving a problem, finding a suitable solution to a problem together teaches students to think wider, deeply analyze the situation, move away from analyzing the situation, paves the way for mental and emotional development.

\section{KEYWORDS}

Pharmacology in higher education, the use of role-based technologies in the lessons "Cardiovascular diseases".

\section{INTRODUCTION}

Lifelong learning role play is a technology that encourages teachers and students to work together. In particular, the role play at the university is a modern technology belonging to the group of advanced pedagogical techniques, methodological tools, active teaching methods. Problem situation, problem solving, search for a suitable solution to a given problem teaches students to think more broadly, to analyze the situation in depth, to move away from the analysis of the situation, their mental abilities pave the way for them to rise to higher levels of self-development [9]. 


\section{THE MAIN FINDINGS AND RESULTS}

Modern pharmacology is a rapidly developing field of medicine that collects the latest information about the achievements of drugs, technologies and the scientific process of treatment in a nutshell. However, in the modern conditions of teaching, there is a need for a more creative approach to the organization of lessons on the basis of new requirements. In this regard, role play technology makes it easy and effective to achieve the educational goals of clinical pharmacology. [1, 2, 3].

It is known that in different countries of the world, complications of atherosclerosis myocardial infarction, cerebrovascular disease and peripheral vascular disease - cause death in $50 \%$ of cases. Atherosclerotic heart disease kills one person every minute in the United States. Atherosclerosis impairs quality of life in millions of people, leading to angina, myocardial infarction, heart failure.

In this article, we present the role play technology that will be used in the training on "Medications for coronary heart disease".

It is recommended to ask the most important questions on the agenda that will induce the student to draw independent conclusions. In particular:

1) Features of the human cardiovascular system. Fundamentals of hemodynamics;

2) Complications of atherosclerosis;

3) Classification of cholesterol, triglycerides and lipoproteins;

4) Apolipoproteins? Statins?

5) Hereditary factors in the development of atherosclerosis. Hereditary forms hyperlipoproteinemia. Dependence of atherosclerosis on various factors: age and risk;
6) Objectives of modern lipid-lowering therapy;

7) Dose-dependent effects of statins. Instructions for use of statins, effects, features of their use in clinical practice, clinically significant interactions;

8) Drug interactions and etc.

The course is designed to: solve situational problems; structure and function of the heart, control of blood circulation; a general audience distribution (for example, about the heart and blood) between role play parts (episodes) used in the lesson for information such as cardiac automatism, systole, and diastole or symptoms, clinical signs, claims of various diseases) can be resolved by distributing cards. For example, they should be used in small groups. Participants: 1. Patient A., 54 years old. 2.Patient's family. 3. The treatment doctor. 4.Professor. 5. Prospective pharmacologists.

Role-play scenario: Patient A., 54 years old. The student in the role of the "patient" describes his symptoms and complaints as if he were examined by a doctor.

The student, who plays the role of the "treatment doctor", describes the patient's medical history: "In the clinical discussion, a patient with a large focal heart attack was seen. At the onset of the disease, heart failure was observed. There was a decrease in chest pain after 7 days of illness, but extrasystolic arrhythmias and increased symptoms of heart failure (abnormal rapid pulse, bluish mucous membranes, swelling of the legs, shortness of breath, decreased diuresis). Blood coagulation tests showed a shortening of the prothrombin cycle".

The patient's family: - You know, doctor, my boss's job requires a lot of attention, so I don't know, this person is very nervous. However, they are indifferent to this situation. 
Professor: Complications of atherosclerosis in many parts of the world - myocardial infarction, cerebrovascular disease and peripheral vascular disease - cause death in 50\% of patients. Atherosclerotic heart disease kills one person every minute in the United States. In millions of people, atherosclerosis impairs quality of life, leading to heart failure. Experimental and epidemiological studies have shown that high blood cholesterol levels ( $>200$ $\mathrm{mg} / \mathrm{dL}$ ) increase the risk of developing clinically specific cardiovascular disease and the resulting deaths (mostly in men). In contrast, $6 \%$ of people have low cholesterol for reasons not related to the heart(cancer, nononcological diseases of the respiratory and digestive organs, trauma, hemorrhagic stroke) increase mortality.

The patient's family told the "Treatment Doctor": - Excuse me, doctor, what are the symptoms of HBV?:

"Treatment Doctor": Angina pectoris (Greek stenos - narrow, short and cardia - heart), heart attack - a common form of ischemic heart disease; sudden onset of cramping pain in the chest area is the main symptom. The pain is behind the chest and can often be felt on the left side of the sternum - in the heart area. Sudden onset of pain can last from a few minutes to half an hour and can spread to the left arm, shoulder, and neck, and sometimes to the right, back, and right arm. Often, pain attacks are accompanied by panic attacks.

"Professor": What drugs would you prescribe for this patient?

"Treatment Doctor": - The following recommendations are given to a patient with acute myocardial infarction on the clinical signs described on day 7 of the disease: depending on the intensity of the attack, painkillers omnopon or droperidol - are prescribed by injection. The use of long-acting agents (sustak, nitron, erinit) to improve intracardiac hemodynamics is effective. Antiarrhythmic drugs (novocaineamide, aymalin, etmosin) can also be used. Cardiac glycosides (digoxin, stelanide), anticoagulants (acetylsalicylic acid) to normalize blood clotting are recommended to normalize heart function and reduce the symptoms of heart failure.

The professor asks future pharmacologists: "What is the cause of the antianginal effect of nitroglycerin in angina pectoris?"

One of the future pharmacologists answers: "The antianginal effect of nitroglycerin in angina pectoris is due to a decrease in myocardial oxygen demand and improved blood supply to the ischemic areas of the myocardium"

“Professor”: True.

“Treatment Doctor": Dear Professor, What would you say about the effectiveness of statins in the treatment of HBV?

"Professor": Statins are now of great importance among lipid-lowering drugs. The first drug, mevastatin (original name compactin), was isolated by Endo in 1976 from cultures of the fungi Penidllium citricum and Penicillium brevicompactum. Lovasta-tin is a product of the vital activity of the fungi Aspergillus terreus and Monascus ruber. The remaining statins are of synthetic origin. I present to you a table with the characteristics of statins (distributes leaflets to young pharmacologists: table 1). 
Table 1

\begin{tabular}{|c|c|c|c|c|c|}
\hline $\begin{array}{c}\text { Lipoprotein } \\
\text { classes }\end{array}$ & $\begin{array}{l}\text { Density } \\
\mathrm{g} / \mathrm{ml}\end{array}$ & $\begin{array}{c}\text { Diameter } \\
\text { NM }\end{array}$ & Essential lipids & $\begin{array}{l}\text { Essential } \\
\text { apolipo } \\
\text { proteins }\end{array}$ & $\begin{array}{c}\text { Mobility in } \\
\text { electrophoresis }\end{array}$ \\
\hline Chylomicrons & $\ll 1.006$ & $500-80$ & $\begin{array}{l}\text { Food } \\
\text { triglycerides }\end{array}$ & $\begin{array}{c}\text { Apo V-48, } \\
\text { Apo A-I, } \\
\text { ApoA-I, } \\
\text { ApoA-IV, } \\
\text { ApoS-P/S-Sh, } \\
\text { Apo ye }\end{array}$ & $\begin{array}{l}\text { Stay on the } \\
\text { starting line }\end{array}$ \\
\hline $\begin{array}{l}\text { VLDL (Very Low } \\
\text { Density } \\
\text { Lipoproteins) }\end{array}$ & $<1.006$ & $80-30$ & $\begin{array}{l}\text { Endogenous } \\
\text { triglycerides }\end{array}$ & $\begin{array}{l}\text { ApoV-10o. } \\
\text { Apo ye. } \\
\text { ApoS-II/C-III }\end{array}$ & Pre- $r$ \\
\hline $\begin{array}{c}\text { Medium } \\
\text { density } \\
\text { lipoproteins }\end{array}$ & $\begin{array}{l}1.006-- \\
1.019\end{array}$ & $35-25$ & $\begin{array}{c}\text { Cholesterol } \\
\text { esters, } \\
\text { triglycerides }\end{array}$ & $\begin{array}{c}\text { Apo V-10o, } \\
\text { Apo ye, Apo } \\
\text { C-II/C-III }\end{array}$ & Slow pre- $\mathrm{R}$ \\
\hline $\begin{array}{c}\text { LDL (low } \\
\text { density } \\
\text { lipoproteins) }\end{array}$ & $\begin{array}{l}1.019-- \\
1.063\end{array}$ & $25-18$ & $\begin{array}{c}\text { Cholesterol } \\
\text { esters }\end{array}$ & Apo V-100 & $R$ \\
\hline $\begin{array}{c}\text { HDL (high } \\
\text { density } \\
\text { lipoproteins) }\end{array}$ & $\begin{array}{l}1.063-- \\
1.210\end{array}$ & $5-12$ & $\begin{array}{c}\text { Cholesterol } \\
\text { esters, } \\
\text { phospholipids }\end{array}$ & $\begin{array}{c}\text { Apo A-I, } \\
\text { ApoA-P. Apo } \\
\text { C-II/C-III }\end{array}$ & $A$ \\
\hline Lipo-protein (a) & $\begin{array}{l}1.055^{--} \\
1.085\end{array}$ & 30 & $\begin{array}{c}\text { Cholesterol } \\
\text { esters }\end{array}$ & $\begin{array}{c}\text { Apo V-10o. } \\
\text { Apo (a) }\end{array}$ & Slow pre- $\mathrm{R}$ \\
\hline
\end{tabular}

Table 1. Lipoprotein classes[10] 
As for the mechanism of action of statins, I will say the following.

You know, in 1913-1915, the young doctors of the St. Petersburg Military Medical Academy, N.N. Anichkov and S.S. Khalatov developed the infiltrative theory of atherosclerosis, which states that "there is no atherosclerosis without cholesterol". Consequently, prescribing lipidlowering drugs is ineffective for people with high blood cholesterol when they have cardiovascular disease or an uncomfortable family history (cardiovascular disease or youth, diabetes in relatives) if a cholesterol-restricted diet is ineffective for 6 months. Primary prophylaxis with multiple lipid-lowering agents can reduce mortality from cardiovascular disease, but mortality from non-heart disease is so high. Only secondary prophylaxis has a positive effect on cardiovascular and mortality in general.

“Treatment Doctor": - Professor, can you provide information on the characteristics of lipoproteins?

"Professor": - Lipids are insoluble in water and are transported in the blood as lipoproteins.

In spherical lipoprotein particles, non-polar lipids - cholesterol esters and triglycerides form a hydrophobic nucleus, while a layer of polar lipids - cholesterol and phospholipids and amphipathic proteins - apolipoproteins are present on the surface. Apolipoproteins provide stability to lipoproteins, act as ligands for cell receptors, and determine the metabolic fate of lipoproteins.

Macrophages, smooth muscles and fibroblasts that break down cholesterol. Cytokines, growth factors and adhesion molecules are involved in atherogenesis - interleukins-1, 2, 6 and 8, tumor necrosis factor-, interferon-, granulocyte-monocytic and monocytic colony stimulating factors, endothelial and platelet growth factors, fibroblast growth factor, endothelin-1, monocytic chymotractor protein.

The goal of modern lipid-lowering therapy is to normalize high levels of atherogenic LDL cholesterol, correct hypertriglyceridemia, and increase cholesterol levels in anti-atherogenic HDL cholesterol. The following classes of lipidlowering drugs are used:

a) statins - inhibitors of reductase Z-hydroxy3-methylglutaryl-co-enzyme L;

b) substances that secrete bile acids;

c) Nicotinic acid;

d) antioxidants of lipoproteins;

e) fibrates.

"Young pharmacologists ": - Dear Professor. What can you say about the consequences of untimely treatment of HBV?

"Professor": Cardiovascular disease remains the leading cause of disability and death worldwide. According to the World Health Organization, $56 \%$ of all deaths are due to cardiovascular disease. In European countries, cardiovascular disease causes 4.3 million (48\%) deaths a year.

According to the State Statistics Committee, $62.1 \%$ of deaths in the Republic of Uzbekistan in January-June 2019 were caused by diseases of the circulatory system [4].

Cardiovascular disease is inextricably linked to lifestyle and existing risk factors. While many risk factors are controlled by lifestyle changes, some (arterial hypertension, dyslipidemia, and diabetes mellitus) can be corrected by medication. 
Young Pharmacologists: - Today we received a lot of information from you about HBV. Thank you very much!

\section{CONCLUSION}

While emphasizing the importance of roleplaying games in continuing education (preschool, secondary, secondary special education), it is worth noting some methodological aspects of it. In particular, the stages of the role play can be conditionally divided into 7 stages:

1. Concentrate. Concentration, motivation for active participation, explanation of the goals of the game;

2. Plan and rules of the game. Explain how the game goes, what the main tasks and features are given, the time of passing the stages of the game;

3. Divide into groups. Distribute and assign tasks to each group;

4. The distribution of roles is done independently by the group or by the teacher;

5. Preparation for the game (reflecting the task received by the groups, entering into the problem, preparing a strategy and giving time for the game);

6. Role play;

7. Feedback. Discuss the game. The discussion takes place in a general context - an analysis of the game.

The role play can be modeled in advance. Distinguish between computer and "live" types of modeling. [8]. "Live" modeling:

1. Scenario identification and preparation (the teacher prepares the script, creates the situation, reflects the problem the audience is working on.
2. Representative of the simulation. The teacher sets the stage for the simulation.

3. Conduct a simulation.

4. Discuss modeling.

8-9 students can take part in the role play, but care should be taken not to turn the episodes of the play into a theatrical version, as the need to strengthen students' knowledge of pharmacology may become a secondary goal. The teacher reads out the list of participants and potential participants to the students. It is important to allow students to freely choose their roles, but it is also effective to involve constantly inactive students in the process at the teacher's initiative.

\section{REFERENCES}

1. Aripova M.L., Axmedova M.X. Pedagogical and psychological significance of the use of game methods in education / Educational technologies. Modern education. №8, 2015.

2. Zhumatova M.G., Kiekova B.Kh. Role play as one of the methods of teaching clinical pharmacology / Vestnik KAZNMU, №3. 2015.

3. Person-centered pedagogical technologies. - Tashkent:, 2013. http://staff.tiiame.uz.

4. Alexandrova E.G., Khaziakhmetova V.N. Discipline program "Medicines affecting the cardiovascular system"; 020400.68 Biology. - Kazan:, 2014.

5. Treatment of cardiovascular diseases. https://kun.uz/60070978. 
6. Classification and types of lipoproteins, causes of lipid imbalance and methods for its correction. https://dkb7.ru/serdtse/klassifikatsiya-iraznovidnosti-lipoproteidov.html.

7. The mechanisms of development of atherosclerosis in obesity. http://bariatric.1spbgmu.ru/zabolev-sogir/12-mekhanizmy-razvitiyaateroskleroza.html.

8. Bordyugova E.V., Pshenichnaya E.V., Dubovaya A.V., Dudchak A.P., Limarenko M.P., Tonkikh N.A., Sokolov V.N., Marchenko E.N. Role play games at the postgraduate stage of study at a medical school. https://cyberleninka.ru/article/n/rolevy e-igry-na-poslediplomnom-etapeobucheniya-v-meditsinskom-vuze.

9. Maxmaraimova Sh., Yakibova D. Speech development through games in physical education classes / NamSU Scientific Bulletin - Scientific bulletin of NamSU. № 9. - Namangan, 2019. - P. $187-1$
10. Classification and varieties of lipoproteins, causes of lipid imbalance and methods of its correction https://dkb7.ru/serdtse/klassifikatsiya-iraznovidnosti-lipoproteidov.html The mechanisms of development of atherosclerosis in obesity http://bariatric.1spbgmu.ru/zabolev-sogir/12-mekhanizmy-razvitiyaateroskleroza.html

11. Kurbonazarova, N. S. (2020). The Linguocultural Aspect Of Ethnographic Units In The Linguistic System (The Example Of Wedding Ceremonies In Surkhandarya). The American Journal of Social Science and Education Innovations, 2(10), 259-263.

12. Kurbonazarova, N. (2019). A REVIEW OF SOME WEDDING CUSTOMS IN THE SURKHANDARYA AREA. Theoretical \& Applied Science, (12), 405-410. 